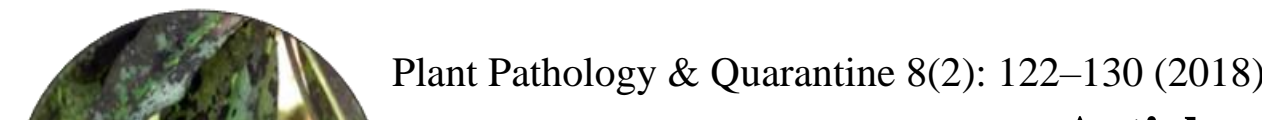

ISSN 2229-2217 www.ppqjournal.org

Article

\author{
Doi 10.5943/ppq/8/2/3 \\ Copyright $(9)$ Agriculture College, Guizhou University
}

\title{
Controlling phytophthora blight of cucumber (Cucumis sativus) in a derived savannah, using different spray intervals of a registered fungicide
}

\author{
Aba SC ${ }^{1}$, Eze SC ${ }^{1}$, Ishieze PU ${ }^{1 *}$, Omeje TE ${ }^{2}$ and Ugwuoke KI ${ }^{1}$ \\ ${ }^{1}$ Department of Crop science, University of Nigeria, Nsukka \\ 2 Department of agronomy, Enugu State polytechnic, Enugu
}

Aba SC, Eze SC, Ishieze PU, Omeje TE, Ugwuoke KI 2018 - Controlling phytophthora blight of cucumber (Cucumis sativus) in a derived savannah, using different spray intervals of a registered fungicide. Plant Pathology \& Quarantine 8(2), 122-130, Doi 10.5943/ppq/8/2/3

\begin{abstract}
Phytophthora blight of cucumber, caused by the oomycete pathogen, Phytophthora capsici causes root and crown rot as well as aerial blight of leaves, fruits and stems. This study was conducted in University of Nigeria Nsukka, south eastern Nigeria, to investigate the effectiveness of four different spray regimes against phytophthora blight. D-D Force insecticide and mancozeb fungicide was used on six cucumber lines (Marketer, Poinsett 76 Netherlands, Poinsett 76 Holland, Poinsett France, Poinsett Holland and Super Marketer) in 2013 farming season. Different spray regimes significantly reduced disease incidence weeks after planting. Disease incidence and severity was highest in the control and lowest when plants were sprayed five times at fortnightly intervals. Best results were obtained with variety Super Marketer and it is therefore recommended for Nsukka farmers.
\end{abstract}

Key words - cucumber - disease incidence - disease severity - spray intervals

\section{Introduction}

Cucumber (Cucumis sativus L.) belongs to the Cucurbitaceae family. It is a monoecious annual climber or creeper (Adetula \& Denton 2003) that has been cultivated for over 3,000 years and is still widely cultivated today. It is soft, succulent with high water content. Cucumber is a major vegetable crop worldwide and develops rapidly, with a shorter time from planting to harvest than for most crops (Wehner \& Guner 2004). The plant has large leaves that form a canopy over the fruit. The vines grow on stakes or on trellises. The fruit is roughly cylindrical and elongated with tapered ends. The fruits are used in unripe matured state, usually eaten raw in salads or pickled, and are also stewed in tropical regions. However, the production of the fruit in Nigeria is very low due to some constraints such as disease, which reduces cucumber fruit yield. Phytophthora blight, caused by the oomycete pathogen, Phytophthora capsici causes root and crown rot as well as aerial blight of leaves, fruits and stems of cucurbits. In Nigeria, adequate research has not been conducted to determine the fungicides and spray regimes to control disease outbreaks, which are common in the south due to warm weather (Okonmah 2011). Fruit are usually under foliage, shading one another, and the plants are allowed to creep on the ground thereby 
having direct contact with some soil inhabiting disease causing organisms. Because of its creeping nature, it predisposes the plant for pests and disease infestation. Torrential rainfall sometimes splash sand on edible fruit, leading to outright degradation of the market quality of fruit. Adequate knowledge of the pest problem at hand led to the use of chemicals (D-D Force insecticide and mancozeb fungicide) as a means of control of phytophthora blight in cucumber production. The intervals for spraying was determined to bring knowledge to farmers regarding the appropriate timing of spraying that is within the economic threshold and also healthy for consumption.

\section{Materials \& Methods}

\section{Experimental site}

The experiments were conducted at the Department of Crop Science Teaching and Research Farm, Faculty of Agriculture, University of Nigeria, Nsukka ( $7^{\circ} 29^{\prime} \mathrm{N}, 6^{\circ} 51^{\prime} \mathrm{E} ; 400$ m.a.s.1.). This experiment evaluated the effect of spray regime on the control of phytophthora blight disease incidence, severity and pod yield on six cucumber lines. Planting was carried out during the 2013 farming season.

Six cucumber lines (Super Marketer, Poinsett France, Poinsett Holland, Poinsett 76 Holland, Poinsett 76 Netherlands and Marketer) were used in the study. The insecticide D-D Force, which contains dichlorvos (DDVP) 1000g/l E.C was applied at 1L/ha using a knapsack sprayer. Fungicide (Z-Force with active ingredient mancozeb $80 \% \mathrm{WP}$ ) was also applied at $2 \mathrm{~kg} / \mathrm{ha}$ at different regimes and intervals (Table 1 ).

\section{Experimental design}

The experiment was laid out as split plot in randomized complete block design of three replications. The spray regimes (Table 2) were assigned to the main plot, while the six cucumber lines were allotted to the sub plots and this was repeated for five months.

\section{Land preparation}

Land measuring $320 \mathrm{~m}^{2}$ was cleared, ploughed and harrowed, before seed beds measuring $2 \times 3 \mathrm{~m}$ were made. Seeds were sown at two seeds per hill at a spacing of $10 \mathrm{~cm}$ within rows and $20 \mathrm{~cm}$ between rows with a planting depth of $2.5 \mathrm{~cm}$ prior to planting, battery cage poultry manure was applied at 3 tonnes per hectare on the readymade bed, one week before planting. The plants got different dosages of the insecticide and the fungicide, some were sprayed fortnightly starting from two weeks after planting, and some were also sprayed at four weeks and six weeks after planting.

\section{Data collection}

Disease incidence and severity data (severity collected and rated as in Table 2) at 2, 4, 6, 8 and 10 weeks after planting were collected. Yield parameters such as fruit girth, fruit length, fruit weight, number of fruit per plant and yield per plant were also determined. Data collected were subjected to analysis of variance (ANOVA) using GENSTAT (2007) 10th edition release statistical software. Mean separation was done using Fishers least significance test at 5\% probability level as described by Obi (2002).

\section{Laboratory analysis}

Apart from observations made in the field, whereby tissues exhibited clear symptoms of phytophthora blight, the causal organism was isolate, whereby the fruit and the stem were washed thoroughly in sterile water. These tissues along with their adjacent small unaffected tissue were cut into $3 \mathrm{~mm}$ squares and a flame sterilized forceps was used to transfer the tissue into a sterile Petri dish containing $0.1 \%$ mercuric chloride solution for surface sterilization of the plant tissues, for 40 seconds. The sterilized tissues were aseptically transferred to Petri dishes containing V8 nutrient agar. The culture that was stored on an agar slant was purified using single hyphal tip method, whereby a small segment of fungal growth in the agar medium was transferred to the centre of Petri 
dishes containing nutrient medium using a flame sterilized inoculation needle and incubated at room temperature. The mycelium continued growing in the medium, the edge of the mycelium developed hyphal tips that are well separated from each other. The hyphal tips were marked by a glass marking pencil and the marked tips along with the agar bits were carefully transferred singly to separate agar slants in tubes using a sterile inoculation needle. The hyphal tips in tubes then developed into pure colonies of Phytophthora capsici. Zoospore production in the V8 agar culture was favoured by incubating at $24^{\circ} \mathrm{C}$ for 72 hours in continuous light. The culture was placed at $5^{\circ} \mathrm{C}$ for 1 hour and incubated at $24^{\circ} \mathrm{C}$ for 60 minutes and zoospores were released.

Table 1 Spray regimes used in the experiment.

\begin{tabular}{ccccccc}
\hline & \multicolumn{7}{c}{ Weeks after planting } & Description \\
\cline { 2 - 6 } Spray regime & 2 & 4 & 6 & 8 & 10 & control \\
\hline No spray & - & - & - & - & - & $5 \times$ \\
2-weekly interval & $*$ & $*$ & $*$ & $*$ & $*$ & $3 \times$ \\
4-weekly interval & $*$ & - & $*$ & - & $*$ & $2 \times$ \\
6-weekly interval & $*$ & - & - & $*$ & - & \\
\hline
\end{tabular}

Table 2 Disease severity ratings.

\begin{tabular}{cc}
\hline Ratings & Percentage \\
\hline 0 & 0 \\
1 & $1-25$ \\
2 & $26-50$ \\
3 & $51-75$ \\
4 & $76-100$ \\
\hline
\end{tabular}

\section{Results}

\section{Laboratory results}

Phytophthora capsici was isolated from infected plant tissues. The hyaline, spherical spores, pointed at the tips and with long pedicel stalk attached to the base of the spore, confirmed the organism as $P$. capsici, causal organism for phytophthora blight of cucumber.

\section{Spray regime effects on disease incidence and severity of the six cucumber lines weeded fortnightly}

Different spray regimes of D-D Force and Z-force significantly $(\mathrm{p}<0.05)$ reduced disease incidence 2, 4, 6, 8, and 10 weeks after planting as compared to the control (Table 3). Disease incidence decreased as the number of sprayings increased, with the best result obtained with five fortnightly sprays.

The mean severity on leaves was significantly influenced by the different spraying schedules of D-D force and Z-force $(\mathrm{p}<0.05)$. The severity was highest at no spray and lowest at $5 \times$ spraying schedule (Table 4). As the spray regime increases, the severity of the phytophthora blight disease severity reduces. The spray regime significantly reduced the disease severity at 2, 4, 6 and 8 weeks after planting, though not significant at 10 weeks after planting. At no spray, $2 \times, 3 \times$, and $5 \times$, it recorded 1.456, 1.440,1.400, and 1.311, respectively. The mean severity of phytophthora blight on fruits was greatly influenced by the spray regimes applied, the spray regime significantly $(\mathrm{p}<0.05)$ controlled the severity of phytophthora blight disease on fruits (Table 5). At no spray, $2 \times, 3 \times$, and $5 \times$, it recorded the following results, respectively $(1.340,1.338,1.305$, and 1.213). 


\section{Yields and yield components (Table 6)}

The fruit girth was affected significantly $(\mathrm{p}<0.05)$ by the different spray regime. The $5 \times$ regime had the highest fruit girth (3.635) while that of no spray was lowest (3.386). The fruit length was also significantly different. The spray regimes used was also highly significant for yield and some of the yield parameters. The yield recorded was 202.2, 210.0, 212.5 and 216.9 tonnes per hectare for no spray, $2 \times, 3 \times$, and $5 \times$, respectively.

\section{Effect of the six cucumber lines on phytophthora blight disease incidence, severity on leaves} and fruits at $2,4,6,8$, and 10 weeks after planting

Disease incidence was significantly different on the various lines of cucumber (Tables 7,8). Poinsett Holland, Poinsett 76 Holland, Poinsett France, Poinsett 76 Netherlands, had higher incidences, while Marketer and Super Marketer had a lower incidence. Super Marketer is the best cucumber line that can resist phytophthora blight disease in this derived savannah.

\section{Response of the six lines of cucumber to disease severity on fruits was statistically significant at 6,8 and 10 weeks after planting (Table 9)}

Super Marketer produced fruits that show fewer symptoms of phytophthora blight disease than other varieties. The six cucumber lines response to yield and number of fruit per plant was highly significant $(<0.05)$. The fruit girth, fruit length and fruit weight differed significantly among varieties (Table 10). Though the yield of the Super Marketer remains the best, the yield of all the lines and the number of fruits per plant also was statistically significant.

\section{Discussion}

Significant differences occurred among the different spray regimes used to control phytophthora blight. The use of D-D Force and Z-force can control, to an extent, outbreak of the disease. McGrath (2001) also found that higher dosage of the pesticides led to better control of phytophthora blight disease of cucumber. Agrios (2004) also found that for many fungal diseases the most effective method of control and sometimes the only one available for disease control is the frequent application of chemical sprays or fungicide dust on the plant, seeds, or into the soil.

Spraying five times at fortnightly intervals was most effective and was still within the economic threshold. Fortnightly spraying gave the highest yield. The observed non-significant variation in 10 weeks after planting on disease severity on leaves may be attributed to the plants being exhausted because at 10 weeks after planting, the leaves have started drooping because harvesting is almost complete and the plants are already senescing.

There were significant differences among the six varieties of cucumber in disease susceptibility. Super Marketer, Poinsett 76 Netherlands and Marketer varieties were superior to Poinsett 76 Holland, Poinsett France and Poinsett Holland. Super Marketer, Poinsett 76 Netherlands and Marketer varieties records were low in both disease incidence, disease severity on both leaves and fruits and yield characters. Super Marketer had differential yield characters - fruit girth, weight of fruit plant and fruit lengths which were significantly different from the other varieties. These differential growth and yield characters of cucumber have been reported by other researchers in different parts of the world. The differences in vegetative and yield characters can be attributed to genetic composition of the varieties used; the Super Marketer may have been quicker in adapting to the environment than the other varieties or the vegetative characters of this variety may have been more active than the other varieties and therefore had a strong source to sink relationship which resulted in high yields experienced in the variety. The number of fruits per plant was higher than that reported by Jizhe (1997) in Thailand. The yields obtained were also higher than what Manyvong (1997) reported in Thailand but the same as the yield obtained by Mingbao (1991).

The high disease incidence and severity recorded in the control spray regime and Poinsett varieties shows that the latter have no resistance trait against blight of cucumber. 
The varieties that performed very well remain the Super Marketer followed by Marketer. The highest sprayed had the least incidence, severity of leaves and fruits and also the highest yield. In conclusion, the $5 \times$ spray regime the lowest disease incidence and severity and the highest yield as compared to other spraying schedules. In this derived savannah, super marketer variety remains the best that can give better yield and also can withstand the phytophthora blight disease and other fungal diseases which are prevalent here. In order to avoid the spread, or even outbreak of phytophthora blight, farmers are advised to spray fortnightly from the day cucumber were planted to avoid crop losses.

Table 3 Effect of spray regime on phytophthora blight disease incidence at different weeks after planting.

\begin{tabular}{|c|c|c|c|c|c|c|c|c|c|c|c|c|}
\hline \multicolumn{13}{|c|}{ Weeks after planting \% } \\
\hline \multirow{2}{*}{$\frac{\text { Spray regime }}{\text { No spray }}$} & \multicolumn{2}{|r|}{2} & \multicolumn{2}{|c|}{4} & \multicolumn{2}{|c|}{6} & \multicolumn{2}{|c|}{8} & \multicolumn{2}{|c|}{10} & \multicolumn{2}{|c|}{ Mean } \\
\hline & 11.560 & $(3.156)$ & 23.220 & $(4.659)$ & 26.560 & $(5.004)$ & 46.780 & $(6.521)$ & 64.890 & (7.693) & 34.602 & $(5.407)$ \\
\hline $2 \times$ & 10.440 & $(3.029)$ & 18.670 & $(4.128)$ & 22.670 & $(4.611)$ & 43.670 & $(6.236)$ & 64.890 & (7.646) & 32.068 & (5.130) \\
\hline $3 x$ & 8.780 & $(2.709)$ & 14.220 & $(3.637)$ & 18.110 & $(4.146)$ & 40.110 & $(5.905)$ & 60.560 & (7.437) & 28.356 & (4.767) \\
\hline $5 x$ & 6.000 & $(2.144)$ & 9.780 & $(2.811)$ & 11.780 & $(3.166)$ & 36.440 & $(5.470)$ & 53.670 & $(6.886)$ & 23.534 & (4.095) \\
\hline Mean & 9.195 & $(2.760)$ & 16.473 & (3.809) & 19.780 & (4.232) & 41.750 & (6.003) & 60.585 & (7.416) & 29.5566 & (4.844) \\
\hline F-LSD (0.05) & & 0.3600 & & 0.3286 & & 0.2994 & & 0.2173 & & 0.2160 & & \\
\hline
\end{tabular}

Spray regime (no spray, $2 \times, 3 \times$ and $5 x$ ) $=$ spray regime at no spray, 2 times, 3 times and 5 times respectively. Values in parenthesis are square-root transformed values to which LSD is applicable

Table 4 Effect of spray regime on phytophthora blight disease severity on leaves at different weeks after planting.

\begin{tabular}{|c|c|c|c|c|c|c|c|c|c|c|c|c|}
\hline \multicolumn{13}{|c|}{ Weeks after planting } \\
\hline \multirow{2}{*}{ Spray regime } & \multicolumn{2}{|r|}{2} & \multicolumn{2}{|r|}{4} & \multicolumn{2}{|r|}{6} & \multicolumn{2}{|r|}{8} & \multicolumn{2}{|r|}{10} & \multicolumn{2}{|c|}{ MEAN } \\
\hline & 0.922 & (1.174) & 1.311 & $(1.331)$ & 1.367 & $(1.345)$ & 2.278 & $(1.623)$ & 2.922 & $(1.807)$ & 1.760 & (1.456) \\
\hline $2 \times$ & 0.822 & $(1.127)$ & 1.144 & $(1.269)$ & 1.444 & $(1.372)$ & 2.289 & $(1.624)$ & 2.933 & $(1.810)$ & 1.726 & (1.440) \\
\hline $3 x$ & 0.689 & $(1.062)$ & 1.011 & $(1.214)$ & 1.289 & $(1.317)$ & 2.211 & (1.599) & 2.933 & $(1.810)$ & 1.627 & (1.400) \\
\hline $5 x$ & 0.533 & $(0.983)$ & 0.733 & $(1.083)$ & 1.000 & (1.199) & 1.933 & $(1.505)$ & 2.867 & (1.786) & 1.413 & (1.311) \\
\hline MEAN & 0.742 & (1.087) & 1.050 & $(1.224)$ & 1.275 & (1.308) & 2.178 & (1.588) & 2.914 & (1.803) & 1.632 & (1.402) \\
\hline F-LSD & & 0.0584 & & 0.0527 & & 0.0543 & & 0.0609 & & NS & & \\
\hline
\end{tabular}

Spray regime (no spray, $2 x, 3 x$ and $5 x$ ) = spray regime at no spray, 2 times, 3 times and 5 times respectively. Values in parenthesis are square-root transformed values to which LSD is applicable. 
Table 5 Effect of spray regime on disease severity on cucumber fruits at different weeks after planting.

\begin{tabular}{|c|c|c|c|c|c|c|c|c|c|c|c|c|}
\hline \multicolumn{13}{|c|}{ Weeks after planting } \\
\hline \multirow{2}{*}{$\begin{array}{c}\text { Spray regime } \\
\text { No spray }\end{array}$} & \multicolumn{2}{|c|}{2} & \multicolumn{2}{|c|}{4} & \multicolumn{2}{|c|}{6} & \multicolumn{2}{|c|}{8} & \multicolumn{2}{|c|}{10} & \multicolumn{2}{|c|}{ MEAN } \\
\hline & - & - & - & - & 0.810 & $(1.106)$ & 1.740 & $(1.440)$ & 1.846 & $(1.485)$ & 1.465 & (1.340) \\
\hline $2 x$ & - & - & - & - & 0.789 & $(1.102)$ & 1.733 & $(1.433)$ & 1.833 & $(1.480)$ & 1.452 & (1.338) \\
\hline $3 x$ & - & - & - & - & 0.678 & $(1.047)$ & 1.622 & (1.389) & 1.833 & $(1.479)$ & 1.378 & (1.305) \\
\hline $5 x$ & - & - & - & - & 0.478 & $(0.954)$ & 1.411 & $(1.297)$ & 1.589 & $(1.388)$ & 1.159 & (1.213) \\
\hline Mean & - & - & - & - & 0.653 & 1.035 & 1.622 & 1.385 & 1.753 & 1.449 & 1.343 & (1.299) \\
\hline F-LSD (0.05) & & - & & - & & 0.0752 & & 0.0568 & & 0.0486 & & \\
\hline
\end{tabular}

Spray regime (no spray, $2 \times, 3 \times$ and $5 x$ ) = spray regime at no spray, 2 times, 3 times and 5 times respectively. Values in parenthesis are square-root transformed values to which LSD is applicable.

Table 6 Effect of spray regime on yield parameters.

\begin{tabular}{|c|c|c|c|c|c|c|}
\hline Spray regime & FG(cm) & FL & FW/PIt(kg) & NFPP & FY(t/ha) & $\mathrm{DF}(\mathrm{t} / \mathrm{ha})$ \\
\hline No spray & 3.386 & 14.862 & 1.084 & 2.885 & 202.200 & 1.063 \\
\hline $2 x$ & 3.562 & 14.997 & 1.083 & 3.313 & 210.000 & 1.084 \\
\hline $3 x$ & 3.580 & 15.139 & 1.050 & 3.333 & 212.500 & 1.050 \\
\hline $5 x$ & 3.635 & 15.479 & 1.011 & 4.454 & 216.900 & 1.011 \\
\hline Mean & 3.541 & 15.119 & 1.057 & 3.496 & 210.400 & 1.052 \\
\hline F-LSD (0.05) & 0.1245 & 0.1876 & 0.0642 & 0.1810 & 11.5600 & 0.0264 \\
\hline
\end{tabular}

Spray regime (no spray, $2 \times, 3 \times$ and $5 \times$ ) $=$ spray regime at no spray, 2 times, 3 times and 5 times respectively. FG $=$ fruit girth, FL $=$ fruit length, FW $=$ fruit weight, NFPP = number of fruit per plant, FY = fruit yield, DF = diseased fruits. 
Table 7 Phytophthora blight disease incidence on six cucumber varieties at different weeks after planting.

\begin{tabular}{|c|c|c|c|c|c|c|c|c|c|c|c|c|}
\hline \multicolumn{13}{|c|}{ Weeks after planting } \\
\hline \multicolumn{2}{|l|}{ Variety } & \multicolumn{2}{|l|}{2} & 4 & \multicolumn{2}{|r|}{6} & \multicolumn{2}{|r|}{8} & \multicolumn{2}{|r|}{10} & \multicolumn{2}{|c|}{ MEAN } \\
\hline$\overline{\mathbf{M}}$ & 9.000 & $(2.707)$ & 17.000 & $(3.914)$ & 19.170 & $(4.191)$ & 39.330 & $(5.735)$ & 61.170 & $(7.424)$ & 29.134 & (4.794) \\
\hline P76H & 10.670 & $(3.085)$ & 20.170 & $(4.296)$ & 22.330 & $(4.586)$ & 42.500 & $(6.130)$ & 64.000 & $(7.632)$ & 31.934 & (5.146) \\
\hline P76N & 10.500 & $(2.919)$ & 14.330 & $(3.561)$ & 18.500 & (4.112) & 42.000 & $(6.080)$ & 60.000 & $(7.380)$ & 29.066 & (4.810) \\
\hline PF & 8.830 & $(2.820)$ & 18.170 & $(4.061)$ & 22.500 & $(4.591)$ & 43.670 & $(6.219)$ & 62.170 & $(7.571)$ & 31.068 & $(5.052)$ \\
\hline PH & 9.830 & $(2.849)$ & 19.170 & (4.119) & 23.830 & $(4.646)$ & 46.000 & $(6.492)$ & 63.500 & $(7.643)$ & 32.466 & (5.150) \\
\hline SM & 6.330 & $(2.177)$ & 10.000 & $(2.903)$ & 12.330 & $(3.265)$ & 37.000 & $(5.541)$ & 52.670 & $(6.844)$ & 23.666 & (4.146) \\
\hline Mean & 9.193 & 2.760 & 16.473 & 3.809 & 19.777 & 4.232 & 41.750 & 6.033 & 60.585 & 7.416 & 29.556 & (4.850) \\
\hline F-LSD (0.05) & & 0.4409 & & 0.4024 & & 0.3667 & & 0.2661 & & 0.2643 & & \\
\hline
\end{tabular}

$\mathrm{M}=$ Marketer, $\mathrm{P} 76 \mathrm{H}=$ Poinsett 76 Holland, P76N $=$ Poinsett 76 Netherlands, PF $=$ Poinsett France, PH = Poinsett Holland, S = Super Marketer.

Values in parenthesis are square-root transformed values to which LSD is applicable.

Table 8 Response of six cucumber lines to disease severity on leaves at different weeks after planting.

\begin{tabular}{|c|c|c|c|c|c|c|c|c|c|c|c|c|}
\hline \multicolumn{13}{|c|}{ Weeks after planting } \\
\hline \multicolumn{2}{|l|}{ Variety } & \multicolumn{2}{|l|}{2} & \multirow{2}{*}{4} & \multicolumn{2}{|r|}{6} & \multirow{2}{*}{\multicolumn{2}{|c|}{8}} & \multicolumn{2}{|r|}{10} & \multicolumn{2}{|c|}{ MEAN } \\
\hline$\overline{\mathbf{M}}$ & 0.583 & $(1.006)$ & 1.000 & & 1.333 & $(1.325)$ & & & 2.950 & $(1.816)$ & 1.687 & (1.410) \\
\hline P76H & 0.750 & $(1.090)$ & 1.200 & $(1.293)$ & 1.450 & $(1.377)$ & 2.433 & (1.673) & 2.933 & $(1.810)$ & 1.753 & (1.449) \\
\hline P76N & 0.700 & (1.069) & 0.933 & $(1.180)$ & 1.167 & $(1.272)$ & 1.933 & $(1.515)$ & 2.900 & (1.798) & 1.527 & (1.367) \\
\hline $\mathbf{P F}$ & 0.917 & $(1.171)$ & 1.233 & $(1.291)$ & 1.333 & $(1.338)$ & 2.050 & $(1.548)$ & 2.933 & $(1.810)$ & 1.693 & (1.432) \\
\hline PH & 0.833 & $(1.136)$ & 1.200 & (1.284) & 1.367 & $(1.336)$ & 2.233 & $(1.608)$ & 2.950 & $(1.816)$ & 1.717 & (1.436) \\
\hline SM & 0.667 & $(1.047))$ & 0.733 & (1.087) & 1.000 & $(1.203)$ & 1.850 & $(1.488)$ & 2.817 & $(1.770)$ & 1.413 & (1.387) \\
\hline Mean & 0.742 & (1.094) & 1.050 & (1.224) & 1.275 & (1.309) & 2.178 & (1.588) & 2.914 & (1.803) & 1.632 & (1.404) \\
\hline F-LSD & & 0.0715 & & 0.0645 & & 0.0665 & & 0.0746 & & NS & & \\
\hline
\end{tabular}

$\mathrm{M}=$ Marketer, $\mathrm{P} 76 \mathrm{H}=$ Poinsett 76 Holland, P76N = Poinsett 76 Netherlands, PF = Poinsett France, PH = Poinsett Holland, $\mathrm{S}=$ Super Marketer.

Values in parenthesis are square-root transformed values to which LSD is applicable. 
Table 9 Response of the six cucumber lines to disease severity on fruit at different weeks after planting.

\begin{tabular}{|c|c|c|c|c|c|c|c|c|c|c|c|c|}
\hline \multicolumn{13}{|c|}{ Weeks after planting } \\
\hline Variety & 2 & \multicolumn{3}{|c|}{4} & 6 & & 8 & \multicolumn{3}{|c|}{10} & \multicolumn{2}{|c|}{ MEAN } \\
\hline $\mathbf{M}$ & - & - & - & - & 0.717 & $(1.073)$ & 1.667 & $(1.392)$ & 1.733 & $(1.446)$ & 1.372 & (1.304) \\
\hline P76H & - & - & - & - & 0.917 & $(1.167)$ & 1.667 & $(1.421)$ & 1.750 & $(1.454)$ & 1.445 & (1.347) \\
\hline P76N & - & - & - & - & 0.483 & $(0.952)$ & 1.633 & $(1.388)$ & 1.750 & $(1.451)$ & 1.289 & (1.264) \\
\hline $\mathbf{P F}$ & - & - & - & - & 0.733 & $(1.073)$ & 1.650 & $(1.406)$ & 1.783 & $(1.456)$ & 1.389 & (1.312) \\
\hline PH & - & - & - & - & 0.817 & $(1.114)$ & 1.683 & $(1.404)$ & 1.933 & $(1.514)$ & 1.478 & (1.344) \\
\hline SM & - & - & - & - & 0.250 & $(0.831)$ & 1.433 & $(1.296)$ & 1.567 & (1.373) & 1.083 & (1.167) \\
\hline Mean & - & - & - & - & 0.653 & (1.035) & 1.622 & (1.385) & 1.753 & (1.449) & 1.343 & (1.290) \\
\hline F-LSD (0.05) & & - & & - & & 0.0921 & & 0.0696 & & 0.0596 & & \\
\hline
\end{tabular}

$\mathrm{M}=$ Marketer, $\mathrm{P} 76 \mathrm{H}=$ Poinsett 76 Holland, P76N = Poinsett 76 Netherlands, PF = Poinsett France, PH = Poinsett Holland, S = Super Marketer.

Values in parenthesis are square-root transformed values to which LSD is applicable.

Table 10 Impact of variety on some yield parameters

\begin{tabular}{lllllll}
\hline Variety & FG(cm) & FL(cm) & FW/PIt (kg) & NFPP & FY (t/ha) & DF (t/ha) \\
\hline M & 3.398 & 14.580 & 1.034 & 3.317 & 206.7 & 1.034 \\
P76H & 3.368 & 14.711 & 1.077 & 3.473 & 215.4 & 1.077 \\
P76N & 3.462 & 15.151 & 1.001 & 3.477 & 200.1 & 1.001 \\
PF & 3.639 & 15.170 & 1.058 & 3.575 & 211.6 & 207.5 \\
PH & 3.515 & 14.857 & 1.037 & 3.519 & 221.1 & 1.058 \\
SM & 3.860 & 16.245 & 1.136 & 3.616 & $\mathbf{2 1 0 . 4 0 0}$ & $\mathbf{1 . 0 5 2}$ \\
Mean & $\mathbf{3 . 5 4 0}$ & $\mathbf{1 5 . 1 1 9}$ & $\mathbf{1 . 0 5 7}$ & $\mathbf{0 . 2 2 1 6}$ & $\mathbf{1 4 . 1 5 0 0}$ & $\mathbf{0 . 0 5 4 7}$ \\
F-LSD (0.05) & $\mathbf{0 . 1 5 2 5}$ & $\mathbf{0 . 2 2 9 7}$ & $\mathbf{0 . 0 7 8 6}$ & $\mathbf{0 . 2 1 6}$ & \\
\hline
\end{tabular}

$\mathrm{M}=$ Marketer, $\mathrm{P} 76 \mathrm{H}=$ Poinsett 76 Holland, P76N = Poinsett 76 Netherlands, PF $=$ Poinsett France, $\mathrm{PH}=$ Poinsett Holland, $\mathrm{S}=$ Super Marketer. FG = fruit girth, $\mathrm{FL}=$ fruit length, $\mathrm{FW}=$ fruit weight, $\mathrm{NFPP}=$ number of fruit per plant, $\mathrm{FY}=$ fruit yield, $\mathrm{DF}=$ diseased fruits. 


\section{References}

Adetula O, Denton L. 2003 - Performance of vegetative and yield accessions of cucumber (Cucumis sativa L.). Horticultural Society of Nigeria (HORTSON), Proceedings of 21st Annual Conference 10-13 Nov, 2003.

Agrios GN. 2004 - Plant Pathology, 5th ed. Elsevier Academic Press. Burlington, MA, USA.

GENSTAT 2007 - GENSTAT Release 7.2, Discovery Edition 3, Lawes Agricultural Trust, Rothamsted Experimental Station, The Netherlands.

Jizhe C.1997 - Cucumber evaluation trial. Report of ARC/AVRDC training workshop held in Bangkok, Thailand.

Larkin RP, Ristaino JB, Campbell CL. 1995 - Detection and quantification of Phytophthora capsici. Phytopathology 85, 1057-1063.

Manyvong V. 1997 - Cucumber varietal trial. Report of ARC/AVRDC training workshop held in Bangkok, Thailand.

McGrath MT. 2001 - Vegetable MD online. Phytophthora blight factsheet.

Mingbao L. 1991 - Cucumber varietal trial. Report of ARC/AVRDC training workshop held in Bangkok, Thailand.

Obi IU. 2002 - Statistical methods in detecting differences between treatment means and research methodology issues in laboratory and field experiment.

Okonmah LU. 2011 - Effects of different types of staking and their cost effectiveness on the growth, yield and yield components of cucumber (Cucumis sativa L.). International Journal of AgriScience 1(5), 292-295.

Wehner TC, Guner N. 2004 - Growth stage, flowering pattern, yield and harvest date prediction of four types of cucumber tested at 10 planting dates. Acta Horticulturae 637.

Wehner TC. 2007 - Cucumber, watermelon, squash and other cucurbits. In Encyclopedia of Food

Culture pp 474-479. 